Research papers

\title{
Riverine input of organic carbon and nitrogen in water-sediment system from the Yellow River estuary reach to the coastal zone of Bohai Sea, China
}

\author{
Chuanyuan Wang*, Yingchun Lv, Yuanwei Li \\ Key Laboratory of Coastal Zone Environmental Processes, Yantai Institute of Coastal Zone Research, Chinese Academy of Sciences, Yantai 264003, China
}

\section{A R T I C L E I N F O}

\section{Keywords:}

Temporal-spatial distribution

Sediment

Suspended matter

Stable isotope

Sources discrimination

Yellow River estuary reach

\begin{abstract}
A B S T R A C T
The temporal-spatial distribution of the carbon and nitrogen contents and their isotopic compositions of suspended matter and sediments from the Yellow River estuary reach (YRER), the estuary to the offshore area were measured to identify the source of organic matter. The higher relative abundances of suspended and sedimentary carbon and nitrogen (POC, TOC, PN and TN) in the offshore marine area compared to those of the riverine and estuarine areas may be due to the cumulative and biological activity impact. The organic matter in surface sediments of YRER, the estuary and offshore area of Bohai Sea is basically the mixture of continental derived material and marine material. The values of $\delta^{13} \mathrm{C}_{\text {sed }}$ fluctuate from values indicative of a land source $(-22.50 \% \pm 0.31)$ to those indicative of a sea source $(-22.80 \% 0 \pm 0.38)$, which can be attributed to the fine particle size and decrease in terrigenous inputs to the offshore marine area. Contrary to the slight increase of POC and PN during the dry season, TOC and TN contents of the surface sediments during the flood season (October) were higher than those during the dry season (April). The seasonal differences in water discharge and suspended sediment discharge of the Yellow River Estuary may result in seasonal variability in TOC, POC, TN and PN concentrations in some degree. Overall, the surface sediments in the offshore area of Bohai Sea are dominated by marine derived organic carbon, which on average, accounts for $58-82 \%$ of TOC when a two endmember mixing model is applied to the isotopic data.
\end{abstract}

\section{Introduction}

Estuaries and coastal zones are the main areas situated between ocean and lands, and they trap significant quantities of natural and anthropogenic organic matter under the interactions of a series of physical, chemical, and biological processes. Carbon cycling in the coastal waters that connect terrestrial and oceanic systems, including rivers, estuaries, tidal wetlands and the continental shelf, is acknowledged to be a major component of global carbon cycle and budget (Bauer et al., 2013; Regnier et al., 2013). Rivers play important roles in the global carbon cycle by linking the land and ocean systems, which are the two largest carbon reservoirs on earth. On a global scale, approximately $900 \mathrm{Tg}\left(\mathrm{Tg}=1 \times 10^{12} \mathrm{~g}\right)$ of carbon from various terrestrial sources, including plants, soils, and the weathering rocks was transported by rivers to the oceans annually (Wang et al., 2012). As over $80 \%$ of global organic carbon burial occurs in shallow marine systems, the organic matter in estuaries and continental shelves plays a key role in the global carbon cycle (Tesi et al., 2007). Furthermore, carbon fluxes along the land-ocean aquatic continuum need to be included in the global carbon dioxide budgets (Regnier et al., 2013). Understanding the fate of terrestrial organic carbon delivered to oceans by rivers is critical for constraining models of biogeochemical cycling and Earth surface evolution. Chinese rivers play a major role in global transport of particulate matter into the ocean (Kaiser et al., 2014). As the 2nd largest river in China and 6th largest river in the world (Bai et al., 2016), the Yellow River carries a huge amount of sediments to the Bohai Sea. The Yellow River Delta (YRD), in the northeast of Shandong Province, China, is one of the most active land-ocean interaction regions among the large river deltas in the world.

It is now well known that most of the riverine organic carbon respired in estuaries enters in the particulate form (POC) and originates from soils, fresh water phytoplankton and sewage (Abril et al., 2003). In recent years, the reduced freshwater and sediment discharge profoundly impacted the physical, biogeochemical and biological environment in the sea surrounding YRD. The idea of water-sediment regulation (WSR) is to regulate and control the flow and sediment transport relationship of the lower reaches through reservoir. The Huanghe Conservancy Commission has implemented a water-sediment regulation scheme (WSRS) since 2002 through the joint operation of three large reservoirs, i.e., the Wanjiazhai, Sanmenxia and Xiaolangdi

\footnotetext{
* Corresponding author.

E-mail address: cywang@yic.ac.cn (C. Wang).
} 
reservoirs, in the middle reaches of the Yellow River. The WSRS is conducted each year from the middle of June, prior to the Yellow River's flood season, and lasts for 15-20 days. The implementation of the WSRS has drastically changed the natural seasonal variations in the water and sediment discharges as well as the properties of the sediment (Wang et al., 2010; Bi et al., 2014). These changes, in turn, have the potential to alter the nature and composition of organic matter of marine deposits as well as their $\mathrm{C} / \mathrm{N}, \delta^{13} \mathrm{C}$ and $\delta^{15} \mathrm{~N}$ values (Owen and Lee, 2004). Furthermore, the rapid economic growth in Bohai Bay raises concerns of significant pollution to aquatic environment, especially to the sediments which act as a natural repository of pollutants.

There are many reports on the environmental aspects of the Yellow River Estuary (Zhang et al., 2008, 2010) and the Bohai Bay, China (e.g. Ma et al., 2001; Hu et al., 2006; Gao and Chen, 2012; Gao et al., 2012). The Yellow River is a massive source of terrestrial organic carbon, but there are only limited data on organic matter distribution and origin in sediments near the Yellow River mouth and in the adjacent shallow Bohai, although they constitute a major carbon sink of global significance (Lin et al., 2014). However, detailed information on the temporal-spatial variability of suspended matter and sedimentary matter of YRD remains scarce, particularly reports concerning covering both the marine area and Yellow River estuary reach (YRER). Thus, the main objectives of this study are as follows: (1) to explore the spatialtemporal variations in organic carbon and nitrogen in sedimentarywater systems covering riverine, estuarial and marine areas, (2) to analyze the factors influencing the carbon and nitrogen contents and isotopic ratios, and discuss their implications for tracing the source of organic matter; and (3) to evaluate the impact of the seasons on the geochemistry of organic carbon and nitrogen in the surface sediments of the Yellow River estuary.

\section{Materials and methods}

\subsection{Study area and sampling methods}

The highest water discharge usually occurs in September while the lowest discharge occurs in April-May, just before the onset of the flood season. The maximum/minimum water discharge ratio at the Lijin Hydrographic Station is 4.1 (Ran et al., 2013). The WSRS in 2012 and 2013 started on 19 June, prior to the Yellow River flood season, and lasted for 20 days. The surface sediments used in this study were collected from the Yellow River estuary reach, the estuary and its offshore area in early October 2012 (Flood season) and late April 2013 (Dry season). The Lijin Hydrographic Station (R1) is the last hydrographic station of the Yellow River and is located $\sim 100 \mathrm{~km}$ upstream of the river mouth (Fig. 1). R9 is the Xintan Oilfield Floating Bridge, which is regarded as the Yellow River's Entrance. YRER refer to stations R1 through R9. The sampling stations were arranged along the Yellow River extending from the YRER (R1-R9) to the estuary (HD1-HD4) and the offshore area of Bohai Sea with two transects (A and C) (Fig. 1, Table 1). The sampling sites included the entire salinity gradient started from the freshwater end-member in the upper reaches of the river estuaries to sea. The surface sediments $(0-2 \mathrm{~cm})$ were collected using a Van Veen style stainless steel grab sampler. After collection, the samples were homogenized, and placed into sterile polyethylene bags, sealed and stored in the dark at $-20^{\circ} \mathrm{C}$ until further was conducted. In order to analyze the correlation between the SPM and sediment, the concurrent samples of surface water ( $0.5 \mathrm{~m}$ depth) from 3 sites (R1, R3, HD3) were also collected in November 2012 and April 2013.

\subsection{Sample preparation and analysis}

\subsubsection{Analysis of grain size of sediments}

The sample granulometry was analyzed on fresh sediments using a Malvern Mastersizer 2000 laser diffractometer capable of analyzing particle sizes between 0.02 and $2000 \mu \mathrm{m}$. The percentages of the following three groups of grain sizes were determined: $<4 \mu \mathrm{m}$ (clay), 4-63 $\mu \mathrm{m}$ (silt), and > $63 \mu \mathrm{m}$ (sand).

\subsubsection{Analyses of total organic carbon and nitrogen}

The sediments were freeze-dried, homogenized and ground in an agate mortar prior to elemental and isotopic analysis. Total carbon (TC) and total nitrogen (TN) were analyzed via high temperature combustion on an Elementar vario MACRO cube CHNS analyzer. After TC measurement, the sediment was decalcified with $10 \% \mathrm{HCl}$, washed twice with deionized water and dried at $60^{\circ} \mathrm{C}$ for total organic carbon (TOC) determination. The total inorganic carbon (TIC) content of the sediment was calculated by substracting TOC from TC. Total inorganic carbon (TIC) analysis was carried out on a Shimadzu TOC- $\mathrm{V}_{\mathrm{CPH}} / \mathrm{SSM}$ 5000A analyzer. TOC in sediments was obtained by subtracting TIC from TC. Duplicate analyses of every sample were run, and the mean of the two measurements are reported here. Replicate analysis of one sample $(n=5)$ gave a $1 \sigma$ precision of $\pm 0.02 \mathrm{wt} \% \mathrm{C}$ and $\pm 0.003 \mathrm{wt} \%$ TN. For isotope analysis, samples were treated with hydrochloric acid to remove carbonate and subsequently rinsed with deionized water to remove salts before drying overnight at $60^{\circ} \mathrm{C}$ (Huon et al., 2002; Hu et al., 2006; Gao et al., 2012).

About $1 \mathrm{~L}$ of water samples was filtered through a pre-combusted (Whatman $0.7-\mu \mathrm{m} \mathrm{GF} / \mathrm{F}$ ) filter at $300^{\circ} \mathrm{C}$ for $6 \mathrm{~h}$ at low vacuum condition and dried at $60{ }^{\circ} \mathrm{C}$ for at least $24 \mathrm{~h}$. Filters were acid fumigated for $12 \mathrm{~h}$ in the desiccators to remove inorganic carbon, and organic carbon and nitrogen on the filter was measured using an elemental analyzer for suspended organic carbon (POC) and suspended organic nitrogen (PN).

\subsubsection{Analyses of stable carbon isotopic composition}

The carbonate free sediments were analyzed by a Finnigan DELTA $^{\text {plus }}$ XL isotope ratio mass spectrometer, and the results were expressed in $\delta$ notation as the deviation from standard reference material in parts per mil (\%):

$\delta^{13} C$ or $\delta^{15} N(\%)=\left(R_{\text {sample }} / R_{\text {reference }}-1\right) \times 1000$

where $R_{\text {sample }}$ and $R_{\text {reference }}$ are the heavy to light isotopic ratios (i.e. ${ }^{13} \mathrm{C} /{ }^{12} \mathrm{C}$ and ${ }^{15} \mathrm{~N} /{ }^{14} \mathrm{~N}$ ) of the sample and reference, respectively. For $\delta^{13} \mathrm{C}$, the reference is Vienna Pee Dee Belemnite (VPDB), and for $\delta^{15} \mathrm{~N}$,
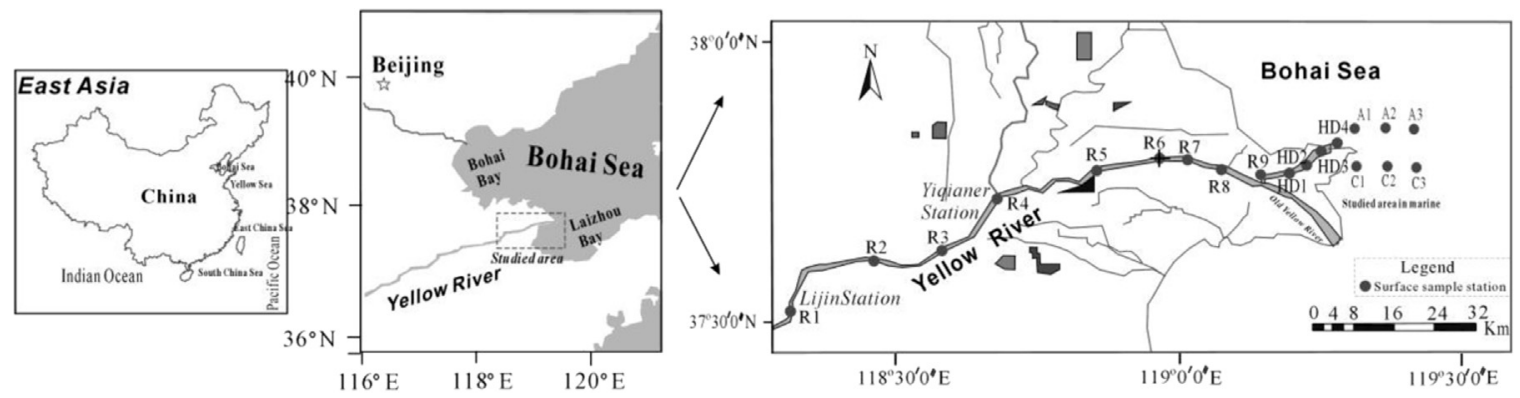

Fig. 1. Location of sampling sites in Yellow River estuary reach. 
Table 1

Sample information, surface water salinity and SPM concentrations from rivers, estuaries and marine.

\begin{tabular}{|c|c|c|c|c|c|c|c|c|c|c|c|c|c|}
\hline \multirow[t]{2}{*}{ Sample } & \multicolumn{9}{|l|}{ River } & \multicolumn{2}{|c|}{ Estuary } & \multirow{2}{*}{\multicolumn{2}{|c|}{$\begin{array}{l}\text { Marine area } \\
\text { Transects A, C }\end{array}$}} \\
\hline & $\mathrm{R} 1$ & $\mathrm{R} 2$ & $\mathrm{R} 3$ & R4 & R5 & R6 & R7 & $\mathrm{R} 8$ & R9 & HK1 & HK3 & & \\
\hline Hydrological Stations & Lijin & $\begin{array}{l}\text { Zhangqiu } \\
\text { wuzi }\end{array}$ & Lianhe & Yiqianer & $\begin{array}{l}\text { Qingjia } \\
3\end{array}$ & $\begin{array}{l}\text { Qingjia } \\
5\end{array}$ & $\begin{array}{l}\text { Qing } \\
7\end{array}$ & $\begin{array}{l}\text { Qingjia } \\
9\end{array}$ & $\begin{array}{l}\text { Cha } \\
3\end{array}$ & - & & - & \\
\hline Distance from estuary $(\mathrm{Km})$ & 127.5 & 97.5 & 85 & 70 & 47.5 & 37.5 & 30 & 22.5 & 7.5 & 0 & 5.0 & ND & ND \\
\hline Surface water Salinity (\%o) & ND & ND & ND & ND & ND & 0.48 & ND & ND & 0.53 & 2.28 & 28.1 & ND & ND \\
\hline $\begin{array}{ll}\text { SPM }(g / L) & \text { Sep. } \\
& \text { Apr. }\end{array}$ & $\begin{array}{l}.74 \\
1.01\end{array}$ & & $\begin{array}{l}0.61 \\
1.13\end{array}$ & & & & & & & & $\begin{array}{l}0.59 \\
0.66\end{array}$ & & \\
\hline
\end{tabular}

Note: ND: not detected.

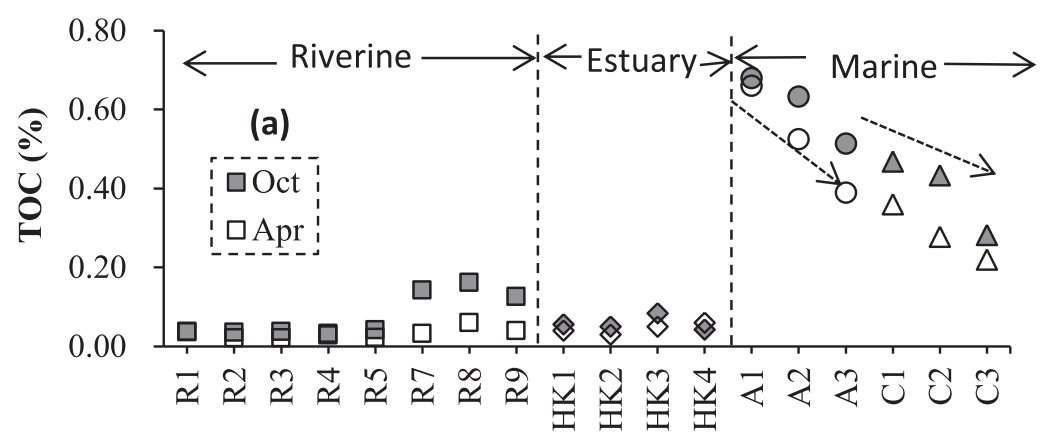

Station ID
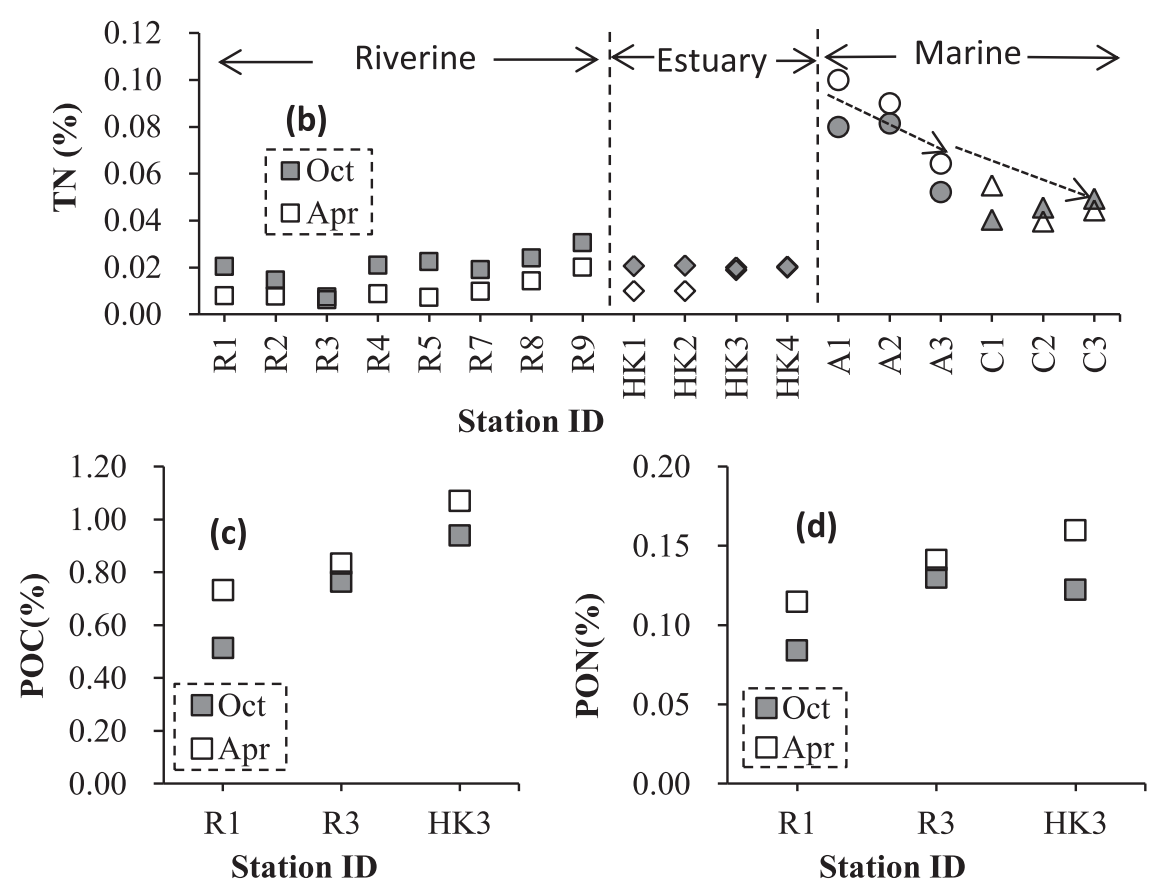

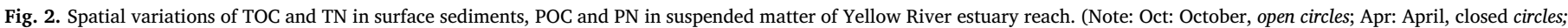
The diagonal arrows in Figure is used to indicate change trends).

it is atmospheric nitrogen. The samples were run in duplicate and the analytical precision was $\pm 0.2 \%$ for $\delta^{13} \mathrm{C}$ and $\pm 0.3 \%$ for $\delta^{15} \mathrm{~N}$.

\section{Results and discussion}

\subsection{Temporal-spatial variability on TOC and TN in sediments and SPM}

As shown in Fig. 2, it is clear that TOC and TN concentrations increase from YRER to the two transects in marine area, which may be due to the accumulation of organic matter in coastal Bohai surface sediments. The TOC contents of surface sediments from the offshore area transect in October 2012 is $0.50 \pm 0.10 \mathrm{wt} \%$, which is higher than that of the riverine sediments of YRER $(0.08 \pm 0.06 \mathrm{wt} \%)$ and estuarine sediments $(0.06 \pm 0.02 \mathrm{wt} \%)$. In addition, the TOC contents of surface sediments from offshore area transect in April 2013 $(0.43 \pm 0.17 \mathrm{wt} \%)$ is also obviously higher than those of the riverine sediments of YRER $(0.03 \pm 0.01 \mathrm{wt} \%)$ and estuarine sediments $(0.05 \pm 0.02 \mathrm{wt} \%)$. These values are largely consistent with those of the Bohai Bay organic matter reported in the literature. It was reported that the TOC contents of Bohai Sea surface sediments ranged broadly 


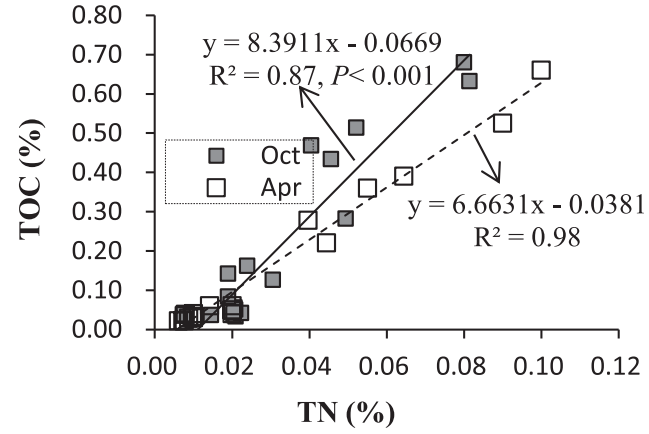

Fig. 3. Relationship between TN and TOC in surface sediments of Yellow River estuary reach.

from $0.04 \mathrm{wt} \%$ to $0.69 \mathrm{wt} \%$ with a mean of $0.38 \pm 0.17 \mathrm{wt} \%$ (Hu et al., 2009). Similar to the TOC, the TN values varied from $0.04 \mathrm{wt} \%$ to $0.09 \mathrm{wt} \%$ with a mean of $0.06 \pm 0.01 \mathrm{wt} \%$ in surface sediments of YRER, which also agree with those reported for Bohai Sea, 0.01-0.10 wt $\%$ with a mean of $0.06 \pm 0.02 \mathrm{wt} \%$ (Hu et al., 2009). The spatial distribution of nitrogen content is similar to that of sedimentary organic carbon (Fig. 2). On the whole, the difference in the TOC and TN for YRER and estuarine sediments is relatively minor. There is a good linear relationship being significant at $P<0.001$ between TOC\% and TN\% as shown in Fig. 3. Similar to the TOC, the TN contents in transects is also obviously higher than that of the riverine and estuarine sediments. Furthermore, TOC and TN concentrations decrease seaward along all the studied transects in coastal Bohai Bay surface sediments.

According to the unpublished TSS data of other research group, the average TSS content in October $(0.81 \pm 0.35)$ is higher than that in April $(0.55 \pm 0.15)$. POC of the Yellow River is lower than that of the global river average, but exhibits a pattern similar to that of other rivers, decreasing logarithmically function with the increasing of TSS concentration. Both POC and PN exhibit weak seasonal changes, with a slight increase in the dry season and particularly the months before the start of the wet season (Fig. 2c,d). Both the carbon and nitrogen contents of the sediment were higher at the mouth of the estuary (Fig. 2a,b). The maximum organic carbon and nitrogen of the suspended matter did not correspond with the maximum organic carbon and nitrogen of the sediments.

\subsection{Factors influencing the distribution of TOC, TN, POC, and $P N$}

The accumulation of organic matter in the sediment was controlled by the material supply and the sedimentary environment. The increasing trends of POC distribution as the Yellow River entered the Bohai Sea, may be caused by the following factors. In the river area, the material supply was dominated by terrestrial input. The deposited matter was mainly composed of large particles with lower POC carried by the river water. The sediment transported in the Yellow River mainly comes from the Loess Plateau, China. The content of the organic matter is low in such loess rich in calcium carbonate. Therefore, the content of POC in YRER $(0.04-0.16 \%)$ is not higher and lower than the corresponding concentrations of the Pearl River Estuary (0.25-1.02\%) (Hu et al., 2006). In addition, the productivity is relatively low in the Yellow River Estuary due to higher water turbidity, which may also contribute to the relatively low TOC of the sediments. The effect of tidal mixing on suspended organic carbon is evident. There is a significant increase trend in the POC\% approaching the end of seawater before flood season, which indicates that primary production of phytoplankton in water is an important source of POC. In the river water area, the biological activity is inhibited by the higher water turbidity and the lower light projection. However, the biological activity is stronger in the sea area due to the abundant light supply. The higher level of life state POC produced in such sea area causes the difference of the POC between

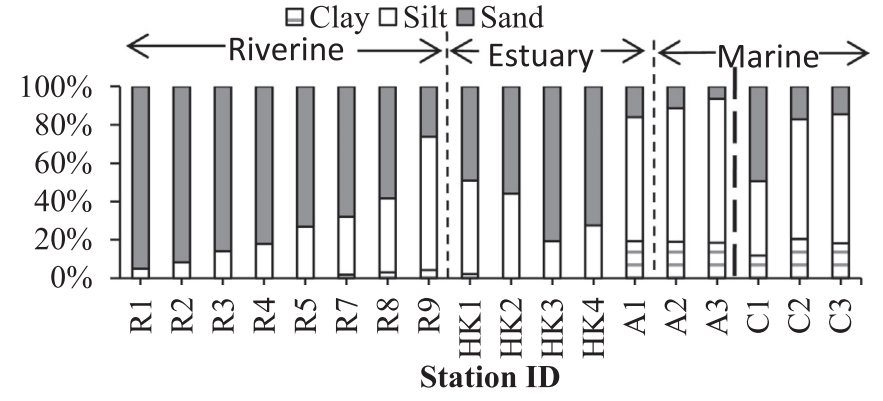

Fig. 4. Ternary diagram showing the sediment classification and deposition patterns in Yellow River estuary reach.

river and marine areas. Microbial activity may promote the degradation of organic matter, which can also significantly reduce the POC content of suspended matter. However, a high salinity water environment ( $28.1 \%$ salinity) can inhibited the growth and reproduction of microorganisms.

The sediment components are mainly composed of sand and silt. The clay component increases from land to sea (Fig. 4). Organic matter is known to be closely associated with fine-grained sediments because of the larger surface area which provides good binding sites for organic matter (Mayer, 1994). In this study, a strong negative correlation is seen between the median grain size (D50) and TOC content for samples from the marine region (Fig. 5). The fine-grained sediments (mud and silt) dominating in the marine area are associated with higher TOC and TN contents, whereas the coarse-grained sediments (silt and sand) in riverine and estuarine area have the lower TOC and TN.

In spite of uncertainties, large and turbid rivers, such as the Amazon, Huanghe, and the Mississippi, deliver sediments that in turn release significant or major fractions of the total riverine nitrogen delivery (Mayer et al., 1998). The overall climate of the Yellow river valley is characterized by the following: four distinct seasons, a dry winter and spring, and wet autumn and summer, and a substantial monsoon (Liu et al., 2009). The large water energy of the wet season results in the transport of the large granular materials particles that are not conducive to the adsorption of POC and PN. There are more fine suspended matter particles in the water in the dry season. A small seasonal variability in TOC and TN concentrations was observed, which is largely consistent with the seasonal variations in water discharge and suspended sediment discharge in the Yellow River Estuary. Terrestrial input is an important source of organic matter for coastal sediments. A large amount of sediment input into the Yellow River may be one of the main reasons for the higher content of TOC and TN in estuarine and coastal sediments during the flood season. The slight decrease of TOC and TN concentrations in April 2013 may be due to the following. In spring (April), the water discharge of the Yellow River was lower than that of observed compared with other seasons, possibly due to decreases precipitation and increased downstream irrigation activities. This resulted in coarser particles settling more easily onto the river bed. In autumn (October), sediments on the river bed were easily re-suspended due to high water discharge, which resulted in high SPM contents with a relatively coarse grain size. The organic matter in sediments is characteristic of mixed terrestrial and marine sources. The chlorophyll concentration of the Bohai Sea increases with the increasing seasonal temperature variation. Thus, the higher primary productivity of the ocean in autumn may also contribute to the variation.

\subsection{Sources of organic matter for the Yellow River estuary reach and the} estuary

Stable carbon and nitrogen isotopes $\left(\delta^{13} \mathrm{C}\right.$ and $\delta^{15} \mathrm{~N}$, respectively) and the ratio of total organic carbon to total nitrogen, which is usually 

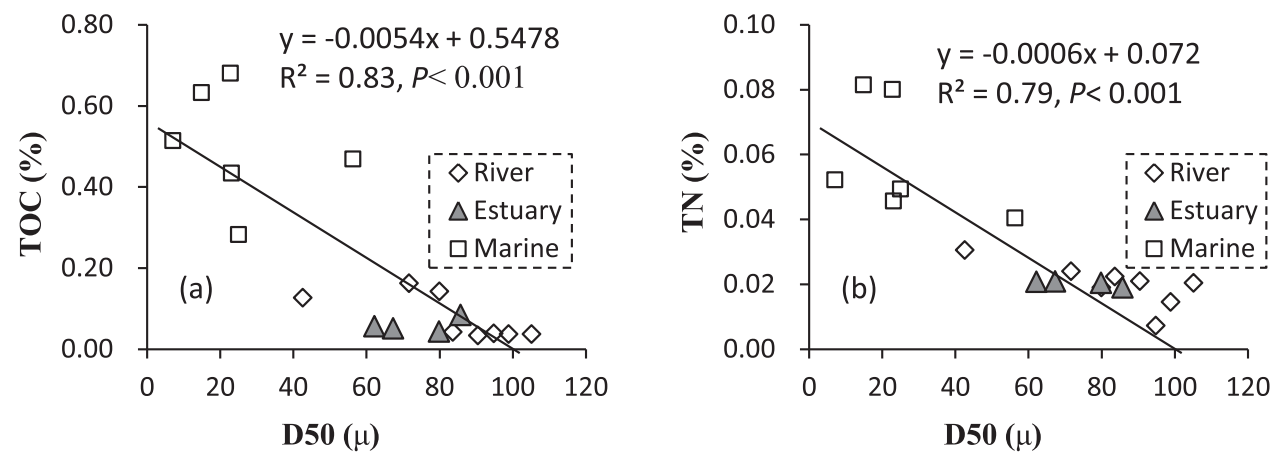

Fig. 5. Relationship between TOC and TN with median grain size (D50) in surface sediments from Yellow River estuary reach.

expressed as $\mathrm{C} / \mathrm{N}$, have been widely used as proxies to elucidate the source and fate of organic matter in aquatic environments (e.g. Thornton and McManus, 1994; Zhou et al., 2006; Kaiser et al., 2014). In general, terrestrial organic matter has lower $\delta^{13} \mathrm{C}$ and $\delta^{15} \mathrm{~N}$ values when compared to marine organic matter (Vizzini et al., 2005). The mixing of organic matter from different sources may result in $\delta^{13} \mathrm{C}, \delta^{15} \mathrm{~N}$ and $\mathrm{C} / \mathrm{N}$ values that fall out of the fields established for terrestrial land plants and phytoplankton, a situation particularly expected in coastal settings (Lamb et al., 2006). Loess from the Loess Plateau, China, serves as the main source of POC in the Yellow River, while contribution from planktons is weak. Typical isotopic composition of marine phytoplankton in temperate seas varied from $-19.1 \%$ to $-22.0 \%$ for $\delta^{13} \mathrm{C}$ (Gearing et al., 1984) and from $3.0 \%$ to $12.0 \%$ for $\delta^{15} \mathrm{~N}$ (Wada and Hattori, 1991). Freshwater phytoplankton isotopic signatures mentioned in the literature have $\delta^{13} \mathrm{C}$ from $-35.0 \%$ to $-25.0 \%$ (Boutton, 1991 ) and $\delta^{15} \mathrm{~N}$ around 5\%o (Wada and Hattori, 1991). Furthermore, the dynamic cycling of nitrogen through various biogeochemical and organic matter degradation processes modifies the TOC/TN ratios and $\delta^{13} \mathrm{C}, \delta^{15} \mathrm{~N}$ to a considerable degree (Gireeshkumar et al., 2013).

\subsubsection{TOC/TN and POC/PN ratios}

The $\mathrm{C} / \mathrm{N}$ ratio can be a potential indicator for differentiating between marine and terrestrial organic matter (e.g. Meyers, 1994, 1997; Graham et al., 2001; Lamb et al., 2006). Generally, marine organic matter and terrestrial organic matter have $\mathrm{C} / \mathrm{N}$ of $\sim 5-8$ and $>15$, respectively (Meyers, 1997). In this study, a significant linear correlation between TOC and TN $\left(r^{2}=0.87, P<0.001\right)$ was shown in Fig. 3 . In this study, TOC/TN ratios varied from 1.6 to 11.59 with an average of $4.77 \pm 2.61$. Based on TOC/TN ratio, about $42 \%$ of stations have a marine source and $19 \%$ of stations have mixed source. Compared with other rivers with high $\mathrm{C} / \mathrm{N}$ ratios (i.e., 8.6-10.9 for the Yangtze; Ran et al., 2013), the Yellow River was characterized by a low $\mathrm{C} / \mathrm{N}$ ratio as a result of its low POC and TOC (Fig. 6). Previous studies have demonstrated that a low $\mathrm{C} / \mathrm{N}$ ratio is indicative of an aquatic origin for POC and TOC, because phytoplankton has an average has a $\mathrm{C} / \mathrm{N}$ ratio of about 6 , while terrestrial POC inputs have higher $\mathrm{C} / \mathrm{N}$ ratios of larger than 8 (Gupta et al., 1997; Lamb et al., 2006). It is worth noting that, the low $\mathrm{C} / \mathrm{N}$ ratios of the suspended matter and sediments from the Yellow River appeared to be contradictory to the common knowledge. A possible explanation for this is the sedimentary rocks and parent soils have the low organic carbon content. Loess from the Loess Plateau, China, serves as the main source of POC in the Yellow River, and the organic matter content is low for loess so rich in calcium carbonate. It can also be seen that the seasonal distribution of TOC/TN and POC/PN is not obvious except for $\mathrm{A} 3, \mathrm{C} 1$, and $\mathrm{C} 2$ stations. The strong decreasing trend in TOC/TN from the river estuary to the shelf is attributed to a progressive seaward decrease in the deposition of terrigenous organic matter and an increase in marine organic matter input (Hu et al., 2006). In accordance with the spatial distribution of TOC and TN, TOC/TN ratios of transects is greater than those of the riverine and estuarine sediments (Fig. 6). This may be due to the preferential degradation of organic matter in the surface sediments of the river estuary. However, such change for transects (A, C) is smaller in this study, which may be due to the shorter length of the studied transects or the mixing effect caused by the complex hydrodynamic conditions. The hydrodynamic conditions in such saltwater-freshwater transitional zone and flat seafloor of this area may also result in the organic matter from marine and terrestrial sources being well mixed.

\subsubsection{Distribution of $\delta^{13} \mathrm{C}$}

Stable carbon isotopic composition has been widely used to distinguish between marine sources and terrestrial plant organic matter sources (e.g. Middelburg and Nieuwenhuize, 1998; Schubert and Calvert, 2001; Middelburg and Hermann, 2007; Ramaswamy et al., 2008). Terrestrial plants with $C_{3}$ pathway have an average $\delta^{13} \mathrm{C}$ value of $-27 \%$, ranging from $-22 \%$ to $-33 \%$, while for the $\mathrm{C}_{4}$ pathway it is from $-9 \%$ to $-16 \%$ (Pancost and Boot, 2004). Guo et al. (2006) reported that $\mathrm{C}_{3}$ plant ecosystem dominated North China; therefore, the portion of organic matter with terrestrial higher plant origin in surface sediments and suspended matter of the studied area is mainly derived from $\mathrm{C}_{3}$ vascular plants. The values of $\delta^{13} \mathrm{C}$ measured for TOC in the surface sediments $\left(\delta^{13} \mathrm{C}_{\text {sed }}\right)$ and the $\delta^{13} \mathrm{C}$ of suspended matter $\left(\delta^{13} \mathrm{C}_{\mathrm{POC}}\right)$ from YRER range from $-23.41 \%$ to $-21.65 \%$, and from $-25.73 \%$ to $-24.88 \%$, respectively, which suggested that the sedimentary organic matter was the mixture of continental derived material and marine material. Significant enrichment in $\delta^{13} \mathrm{C}_{\mathrm{POC}}$ from the upper estuary to the lower estuary in suspended matter approaching the marine phytoplankton ratio (Fig. 7), suggests a corresponding decrease in the influence of terrigenous matter toward the mouth of the estuary (Ramaswamy et al., 2008; Hu et al., 2009). Since it is controlled by biological geochemistry, $\delta^{13} \mathrm{C}$ value of terrestrial organic matter is lower than that of marine organic matter. Not consistent with $\delta^{13} \mathrm{C}_{\mathrm{POC}}$, such difference of $\delta^{13} \mathrm{C}_{\text {sed }}$ values among riverine, estuarine and marine samples in this study is not obvious (Fig. 7), which may be due to the alteration of carbon isotopic composition by the factors, such as sediment resuspension, biological activities, under the complex coastal zone environmental conditions. For example, the seasonal variations of $\delta^{13} \mathrm{C}$ and $\delta^{15} \mathrm{~N}$ were largely attributed to the SPM composition change in Changjiang (Yangtze River) Estuary, i.e., more phytoplankton cells in the summer whereas more resuspended sediment particles were present in winter (Gao et al., 2014). However, the values of $\delta^{13} \mathrm{C}_{\text {sed }}$ exhibited some fluctuation from land $(-22.50 \%$ o \pm 0.31$)$ to sea $(-22.80 \%$ \pm 0.38$)$, which were probably due to the decreasing amount of fine particles in the terrigenous input in offshore marine area. The particulate organic carbon carried by the Yellow River mainly comes from the contribution of older carbon, such as premature soil and sedimentary rocks in the Yellow River basin, and the contribution of other sources is easy to cover when the amount of these two is in absolute predominance. Such mentioned may suggest little isotopic differences in this study. This is consistent with the distribution features of carbon isotope in the Yangtze River Delta region.

It can also be seen that the $\delta^{13} \mathrm{C}_{\mathrm{POC}}$ and $\delta^{13} \mathrm{C}_{\text {Sed }}$ (Riverine and 


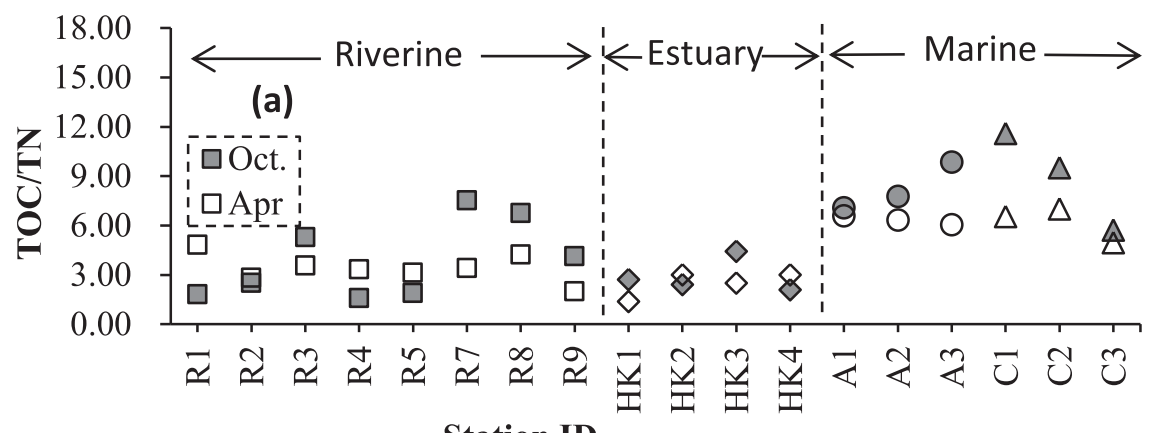

Station ID

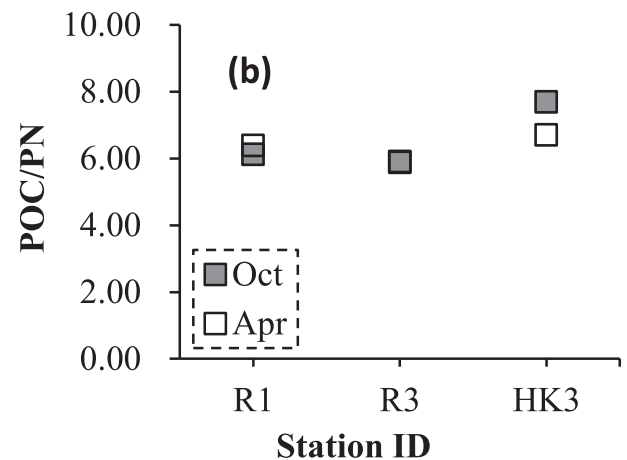

Fig. 6. Spatial variations of $\mathrm{C} / \mathrm{N}$ ratios in surface sediments and suspended matter of Yellow River estuary reach. (Note: Oct: October, open circles; Apr: April, closed circles).

Estuarine areas) are slightly heavier after flooding season than before flooding season (Fig. 7). This phenomenon was largely consistent with the seasonal variations in water discharge and suspended sediment discharge observed in the Yellow River Estuary. These variations led to the sedimentation of large amounts of terrigenous organic matter with higher $\delta^{13} \mathrm{C}$ signatures along the Yellow River estuarine during the flood seasons. Therefore, we conclude that the water discharge of the Yellow River dominates the seasonal fluctuation of $\delta^{13} \mathrm{C}$.

\subsubsection{Distribution of $\delta^{15} N$}

Marine organic matter usually has the $\delta^{15} \mathrm{~N}$ value of $3-12 \%$ with the mean of $5-7 \%$ as derived from phytoplankton which normally use dissolved nitrate (Brandes and Devol, 2002; Lamb et al., 2006). Organic matter derived from nitrogen fixing land plants has $\delta^{15} \mathrm{~N}$ values of approximately zero, whereas plants using only mineral $\mathrm{N}$ derived from soil $\left(\mathrm{NO}_{3}{ }^{-}\right.$or $\left.\mathrm{NH}_{4}{ }^{+}\right)$have usually positive $\delta^{15} \mathrm{~N}$ values. The $\delta^{15} \mathrm{~N}$ values of in suspended matter of Yellow River were reported to range from $3.2 \%$ to $4.5 \%$ o (Liu et al., 2015), which is consistent with our data $(1.58-5.18 \%)$. Anthropogenic perturbation may have increased the

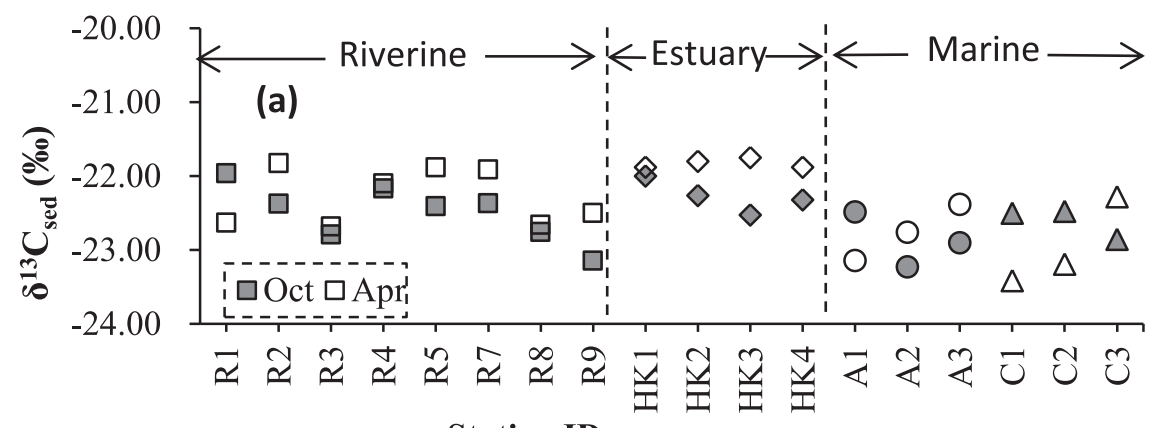

Station ID

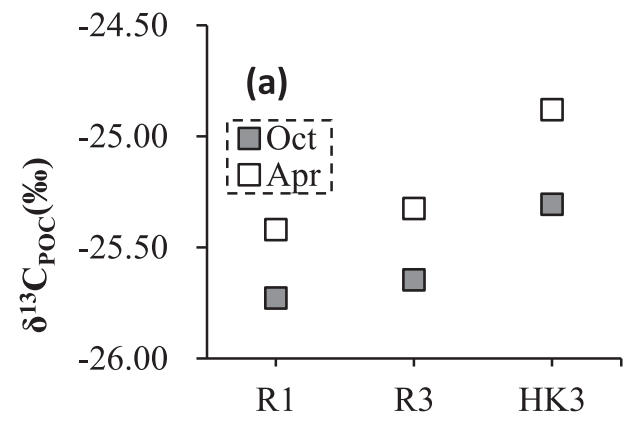

Station ID

Fig. 7. Spatial variations of $\delta^{13} \mathrm{C}$ in surface sediments (a) and suspended matter (b) of Yellow River estuary reach. (Note: Oct: October, open circles; Apr: April, closed circles). 

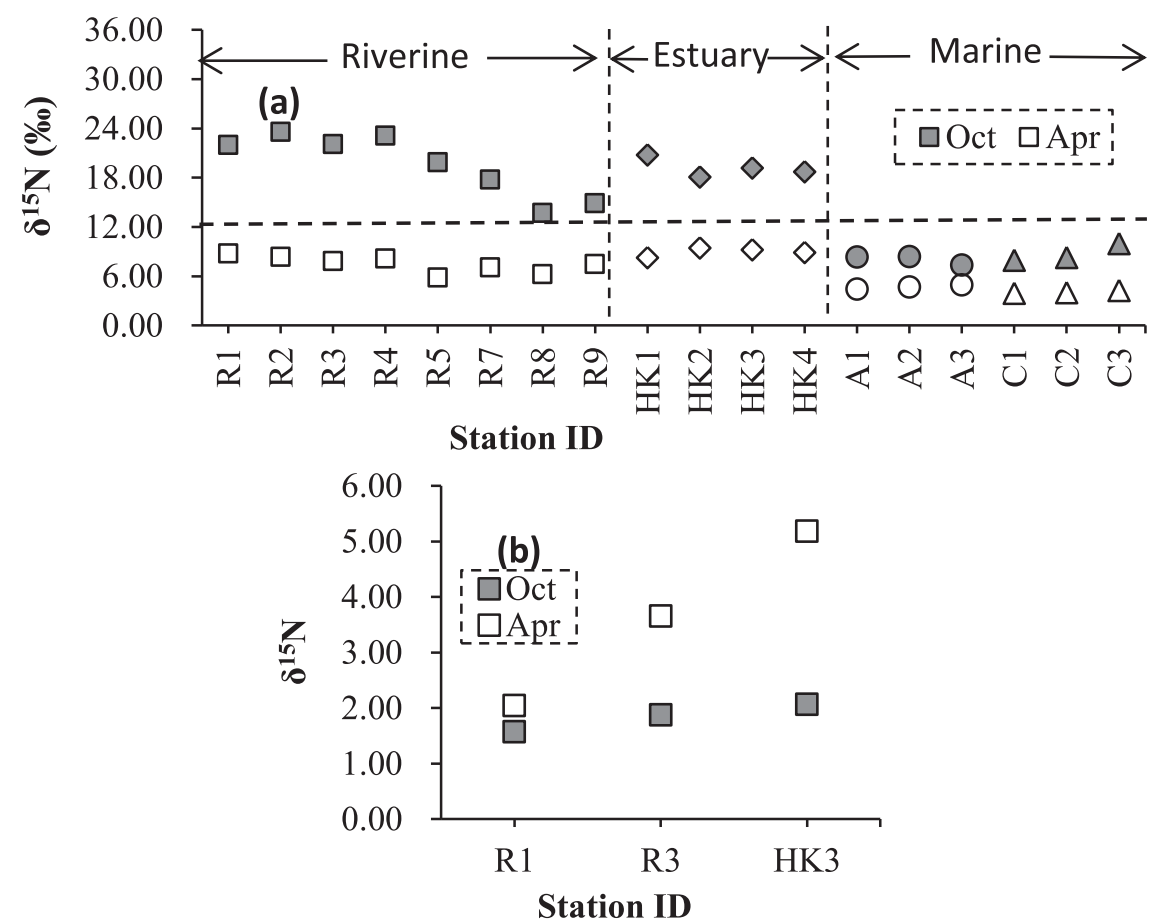

Fig. 8. Spatial variations of $\delta^{15} \mathrm{~N}$ in surface sediments (a) and suspended matter (b) of Yellow River estuary reach. (Note: Oct: October, open circles; Apr: April, closed circles).

flux of carbon to inland waters (Regnier et al., 2013). The spatial heterogeneity of both $\delta^{13} \mathrm{C}$ and $\delta^{15} \mathrm{~N}$ values indicated that Yellow River sediment transport and anthropogenic wastewater discharge were two driving forces for the sedimentary organic carbon and nitrogen dynamics in large river plume and inner bay areas (Li et al., 2016). The $\delta^{15} \mathrm{~N}$ of the river's suspended matter is quite variable, but it is lower than that of the sedimentary organic matter $(5.87-23.61 \%)$, due to the contributions from terrestrial plant and soil nitrogen. The $\delta^{15} \mathrm{~N}$ value of sediment and SPM both exhibit increasing trends from land to sea. As mentioned above, in this study, the $\delta^{15} \mathrm{~N}$ values of the surface sediments from riverine sampling sites are apparently higher than that from the marine region due to stronger anthropogenic activities effect in Yellow River (Fig. 8). As the anthropogenic N-fertilizer input in the bay area could lead to enriched $\delta^{15} \mathrm{~N}$ values through $\mathrm{NH}_{3}$ volatilization and assimilation as well as nitrification-denitrification process. The wastewater was usually characterized by enriched $\delta^{15} \mathrm{~N}$ values which could be above $10 \%$ (McKinney et al., 2001). It can also been see that $\delta^{15} \mathrm{~N}_{\mathrm{PN}}$ and $\delta^{15} \mathrm{~N}_{\text {sed }}$ (Riverine and Estuarine areas) are slightly heavier after the flooding season compared with those of the dry season. High discharge in the wet season favors the transport of the large granular materials particles, which is not conducive to the adsorption of PN.

Nitrogen isotopic compositions could be easily modified by a series of complex biogeochemical processes on some time scales (Gao et al., 2012). Dynamic cycling of nitrogen is subject to kinetic isotope fraction effects especially during the biogenic transformation and recycling of dissolved and particulate nitrogen compounds (Cifuentes et al., 1996; Wu et al., 2003). Liu et al. (2006) reported that heavier $\delta^{15} \mathrm{~N}$ values significantly corresponded with higher $\mathrm{C} / \mathrm{N}$ ratios in intertidal sediments from the Yangtze Estuary, China, and the authors ascribed this relationship to the result of organic matter diagenesis. However, it is shown that, similar to $\delta^{13} \mathrm{C}, \delta^{15} \mathrm{~N}$ against $\mathrm{C} / \mathrm{N}$ ratios also has no pronounced relationship in this study (Fig. 9). It may be due to the complex mixed sources, especially the anthropogenic N-fertilizer input. The organic matter diagenesis has little effect on the variety of nitrogen isotopic compositions in this study. It has also been reported that higher decomposed organic matter will contain little nitrogen enriched in ${ }^{15} \mathrm{~N}$ (Caraco et al., 1998).

\subsection{Contribution of terrigenous and autogenous organic carbon}

The $\delta^{13} \mathrm{C}$ and $\delta^{15} \mathrm{~N}$ values of the sediments are between those of terrestrial and marine sources, which indicate that the organic matter in sediments is characterized by mixed terrestrial and marine sources (Fig. 10). To assess the relative proportions of terrigenous and marine autogenous organic carbon (AOC) present in the sediments, a simple $\delta^{13} \mathrm{C}$-based two end-member mixing model based on the work of Calder and Parker (1968) and adopted by other researchers such as Schlunz et al. (1999) and Hu et al. (2006) was applied to this area. We used $-27.0 \%$ as the $\delta^{13} \mathrm{C}$ value of terrestrial end-member $\left(\delta^{13} C_{\text {terrestrial }}\right)$ based on the $\delta^{13} \mathrm{C}$ value of sediments from land environment in coastal zone of Bohai Bay. This value is close to that of $\mathrm{C}_{3}$ plants that dominate in northern China (Guo et al., 2006; Liu et al., 2015). Likewise, we assumed $-20.5 \%$ as the $\delta^{13} \mathrm{C}$ value of marine end-member $\left(\delta^{13} C_{\text {marine }}\right)$ (Jia and Peng, 2003; Gao et al., 2012). The calculation of terrestrial organic carbon contribution $(f)$ was obtained using the following equation:

$f(\%)=\left(\delta^{13} C_{\text {marine }}-\delta^{13} C_{\text {measured }}\right) /\left(\delta^{13} C_{\text {marine }}-\delta^{13} C_{\text {terrestrial }}\right) \times 100$

Then the contribution of marine algae $\left(f^{\prime}\right)$ to the TOC was estimated using the following expression:

$f^{\prime}(\%)=100-f$

The AOC content was obtained from the following equation:

$A O C=T O C \times f^{\prime} \%$

As shown in Fig. 11, the AOC concentrations generally decrease seaward along transects A and C. This can be explained by the growth of the marine primary producers in response to the input of nutrients to this area transported from the land by the surrounding rivers. The resulting estimates of the contributions of the terrestrial and autogenous organic carbon to the sediments of offshore area are also summarized in Fig. 11. In summary, the surface sediments in the offshore area are dominated by marine derived organic carbon, which on average, accounts for $65.52 \%$ and $65.47 \%$ of their TOC concentrations in October and April, respectively. The contribution of AOC to TOC increases 

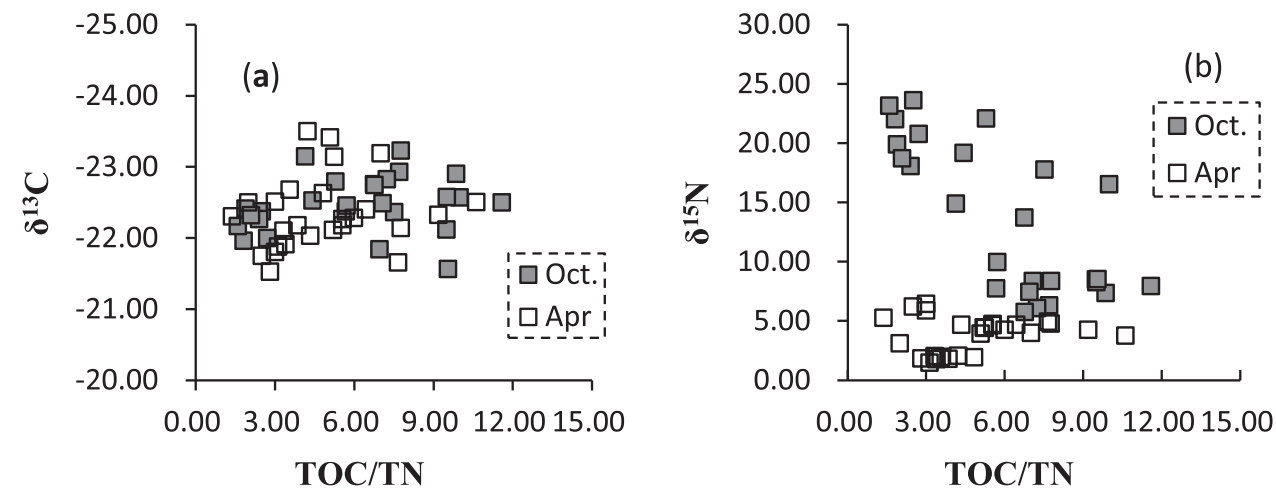

Fig. 9. Relationship between $\delta^{13} \mathrm{C}$ and TOC/TN ratios (a) and $\delta^{15} \mathrm{~N}$ and TOC/TN ratios (b) in surface sediments of Yellow River estuary reach.

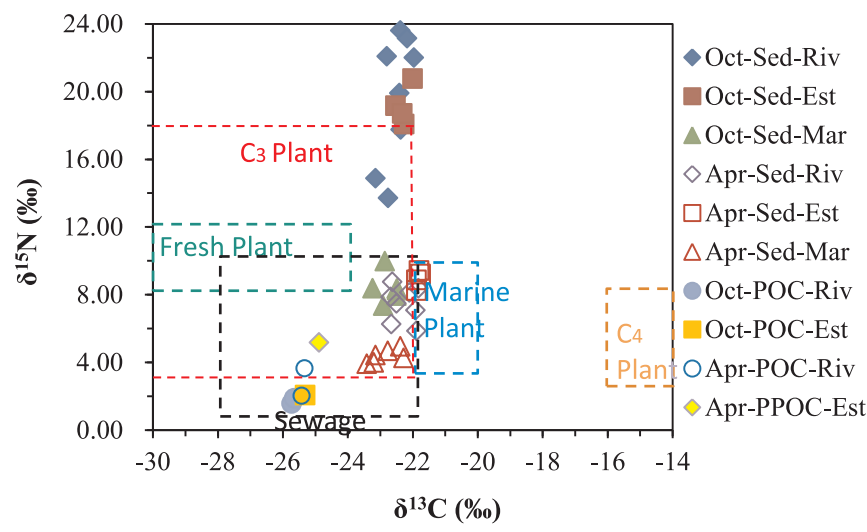

Fig. 10. Plot of carbon and nitrogen stable ratios in surface sediments and suspended matter of Yellow River estuary reach. (Note: Riv: Riverine, Est: Esturine; Mar: Marine).

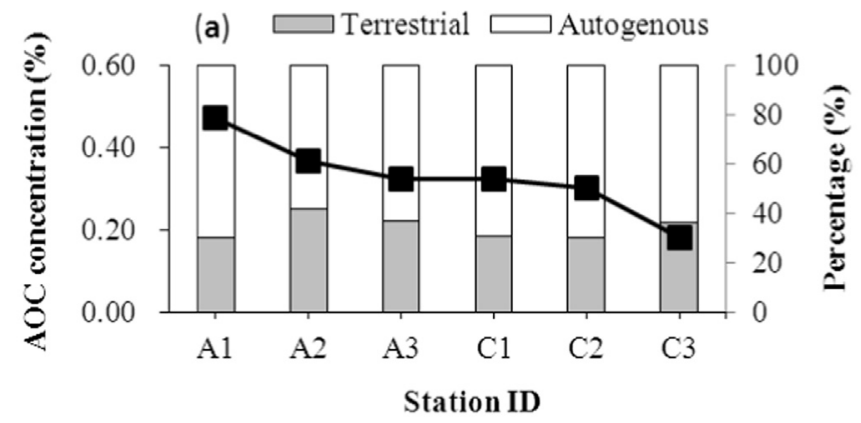

(b) $\square$ Terrestrial $\square$ Autogenous

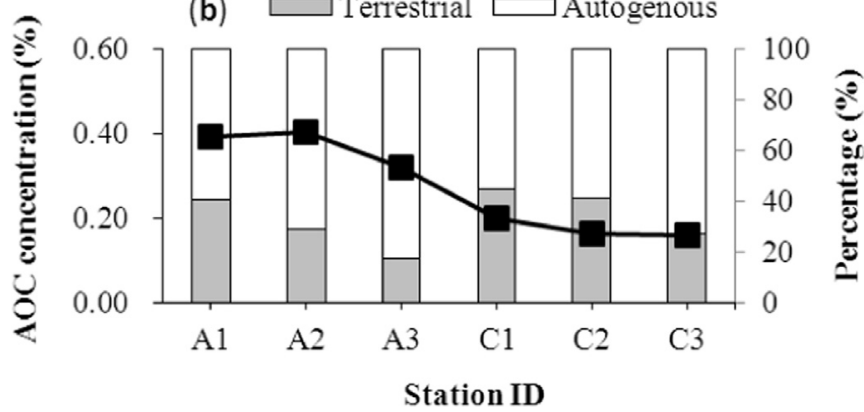

Fig. 11. AOC concentration and relative contribution of terrestrial and autogenous organic carbon in surface sediments in October (a) and April (b) from Yellow River estuary reach.

seaward along transects A and C. The relative proportion of autogenic and terrestrial organic carbon in sediments is the integrated result of any natural and anthropogenic processes that influence the biogeochemical cycle of TOC such as waste discharge, hydrodynamics, primary production in the overlying water body and early diagenesis.

\section{Conclusions}

In this study, spatial variations of total organic carbon, total nitrogen and their isotopes were observed in surface sediments and suspended matter from Yellow River Delta and its adjacent sea area. Our findings indicate that the spatial distributions of TOC, TN in surficial sediments and POC, PN in suspended matter from the coastal Bohai are consistent with their average values being higher in offshore sediments than in riverine ones. The higher relative abundance of TOC and TN in the marine samples than riverine and estuary samples may be due to the cumulative impact and biological activity. Furthermore, the TOC and TN contents of surface sediments during the flood season (October) were higher than those during dry season (April), which was probably due to significant riverine inputs of organic matter from Yellow River in WSRS and flood season. The slight decrease of POC and PN concentrations in October 2012, may be due to the greater ability of river to transport larger particles in wet season. The spatial distributions of TOC, TN and their isotopic signatures in marine sediments are mainly controlled by the mixing inputs of terrigenous and marine components. Significant enrichment in $\delta^{13} \mathrm{C}$ from YRER, to the estuary to marine area in both the suspended matter and sediment indicates a decrease in the influence of terrigenous material toward the mouth of the estuary. Both POC and PN exhibited weak seasonal changes, with a slight increase in the dry season. Larger amounts of terrigenous organic matter with lower $\delta^{13} \mathrm{C}$ signatures and nitrogen derived from human wastewater in the flood seasons leads to $\delta^{15} \mathrm{~N}$ enrichment, more negative $\delta^{13} \mathrm{C}$ and more abundant TOC and TN in sediments. The organic matter in marine sediments is predominately from an autochthonous source, and the estimated autochthonous organic carbon is about $58-82 \%$ of TOC. The results of this study imply qualitatively that, in YRER, particulate organic matter from anthropogenic sources is mainly trapped in riverine sediments. As sedimentary organic carbon is the most important carrier of persistent organic pollutants, the spatial distribution pattern of organic carbon indicates that greater attention should be paid to the riverine sediments for environmental monitoring and risk assessment of the coastal Bohai Bay area.

\section{Acknowledgements}

This study was co-supported by Science and Technology Service Network Initiative, Chinese Academy of Sciences (KFJ-EW-STS-127), International cooperation, CAS, Chinese-foreign cooperation in key projects (133337KYSB20160002), and Project of on-site sediment microbial remediation of public area of central Bohai Sea, North China Sea Branch of State Oceanic Administration (QDZC20150420-002). We would like to thank LetPub (www.letpub.com) for providing linguistic assistance during the preparation of this manuscript. 


\section{References}

Abril, G., Etcheber, H., Delille, B., Frankignoulle, M., Borges, A.V., 2003. Carbonate dissolution in the turbid and eutrophic Loire estuary. Mar. Ecol. Prog. 259, 129-138.

Bai, P., Liu, X.M., Liang, K., Liu, C.M., 2016. Investigation of changes in the annual maximum flood in the Yellow River basin, China. Quatern. Int. 392, 168-177.

Bauer, J.E., Cai, W.J., Raymond, P.A., Bianchi, T.S., Hopkinson, C.S., Regnier, P.A.G., 2013. The changing carbon cycle of the coastal ocean. Nature 504, 61-70.

Bi, N.S., Yang, Z.S., Wang, H.J., Xu, C.L., Guo, Z.G., 2014. Impact of artificial water and sediment discharge regulation in the Huanghe (Yellow River) on the transport of particulate heavy metals to the sea. Catena 121, 232-240.

Boutton, T.W., 1991. Stable carbon isotope ratios of natural materials: II. Atmospheric terrestrial, marine, and freshwater environments. In: Coleman, D.C., Fry, B. (Eds.), Carbon Isotopes Techniques. Academic Press, San Diego, pp. 173-185.

Brandes, J.A., Devol, A.H., 2002. A global marine-fixed nitrogen isotopic budget: implications for Holocene nitrogen cycling. Glob. Biogeochem. 16, 1120-1134.

Caraco, N.F., Lampman, G., Cole, J.J., Limburg, K.E., Pace, M.L., Fisher, D., 1998. Microbial assimilation of DIN in a nitrogen-rich Estuary: implication for food quality and isotope studies. Mar. Ecol. Prog. Ser. 167, 59-71.

Calder, J.A., Parker, P.L., 1968. Stable carbon isotope ratios as indices of petrochemical pollution of aquatic systems. Environ. Sci. Technol. 2, 535-539.

Cifuentes, L.A., Coffins, R.B., Slolrzano, L., Cardenas, W., Espinoza, J., Teilley, R.R., 1996. Isotopic and elemental variations of carbon and nitrogen in a mangrove Estuary. Estuar. Coast. Shelf Sci. 43, 781-800.

Gao, L., Li, D.J., Ishizaka, J., 2014. Stable isotope ratios of carbon and nitrogen in suspended organic matter: Seasonal and spatial dynamics along the Changjiang (Yangtze River) transport pathway. J. Geophys. Res. Biogeosci. 119, 1717-1737.

Gao, X.L., Chen, C.T.A., 2012. Heavy metal pollution status in surface sediments of the coastal Bohai Bay. Water Res. 46, 1901-1911.

Gao, X.L., Yang, Y.W., Wang, C.Y., 2012. Geochemistry of organic carbon and nitrogen in surface sediments of coastal Bohai Bay inferred from their ratios and stable isotopic signatures. Mar. Pollut. Bull. 64, 1148-1155.

Gearing, G.N., Gearing, P.L., Rudnick, D.T., Requejo, A.G., Hutchins, M.J., 1984. Isotope variability of organic carbon in a phytoplankton based temperate estuary. Geochim. Cosmochim. Acta 48, 1089-1098.

Gireeshkumar, T.R., Deepulal, P.M., Chandramohanakumar, N., 2013. Distribution and sources of sedimentary organic matter in a tropical estuary, south west coast of india (cochin estuary): a baseline study. Mar. Pollut. Bull. 66, 239-245.

Graham, M.C., Eaves, M.A., Farmer, J.G., Dobson, J., Fallick, A.E., 2001. A study of carbon and nitrogen stable isotope and elemental ratios as potential indicators of source and fate of organic matter in sediments of the Forth Estuary, Scotland. Estuar. Coast. Shelf Sci. 52, 375-380.

Guo, Z.G., Li, J.Y., Feng, J.L., Fang, M., Yang, Z.S., 2006. Compound-specific carbon isotope compositions of individual long-chain $n$-alkanes in severe Asian dust episodes in the North China coast in 2002. Chinese. Sci. Bull. 51, 2133-2140.

Gupta, L.P., Subramanian, V., Ittekkot, V., 1997. Biogeochemistry of particulate organic matter transported by the Godavari River, India. Biogeochemistry 38, 103-128.

Hu, J., Peng, P., Jia, G., Mai, B., Zhang, G., 2006. Distribution and sources of organic carbon, nitrogen and their isotopes in sediments of the subtropical Pearl River estuary and adjacent shelf, Southern China. Mar. Chem. 98, 274-285.

Hu, L., Guo, Z., Feng, J., Yang, Z., Fang, M., 2009. Distributions and sources of bulk organic matter and aliphatic hydrocarbons in surface sediments of the Bohai Sea, China. Mar. Chem. 113, 197-211.

Huon, S., Grousset, F.E., Burdloff, D., Bardoux, G., Mariotti, A., 2002. Sources of finesized OM in North Atlantic Heinrich layers: $\delta^{13} \mathrm{C}$ and $\delta^{15} \mathrm{~N}$ tracers. Geochim. Cosmochim. Acta 66, 223-239.

Jia, G.D., Peng, P.A., 2003. Temporal and spatial variations in signatures of sedimented organic matter in Lingding Bay (Pearl estuary), southern China. Mar. Chem. 82, 47-54.

Kaiser, D., Unger, D., Qiu, G.L., 2014. Particulate organic matter dynamics in coastal systems of the northern Beibu Gulf. Cont. Shelf Res. 82, 99-118.

Lamb, A.L., Wilson, G.P., Leng, M.J., 2006. A review of coastal palaeoclimate and relative sea-level reconstructions using $\delta^{13} \mathrm{C}$ and $\mathrm{C} / \mathrm{N}$ ratios in organic material. Earth-Sci. Rev. 75, 29-57.

Li, Y., Zhang, H., Tu, C., Fu, C., Xue, Y., Luo, Y., 2016. Sources and fate of organic carbon and nitrogen from land to ocean: identified by coupling stable isotopes with $\mathrm{C} / \mathrm{N}$ ratio. Estuar. Coast. Shelf Sci. 181, 114-122.

Lin, T., Wang, L., Chen, Y., Tian, C., Pan, X., Tang, J., Li, J., 2014. Sources and preservation of sedimentary organic matter in the Southern Bohai Sea and the Yellow Sea: evidence from lipid biomarkers. Mar. Pollut. Bull. 86, 210-218.

Liu, M., Hou, L.J., Xu, S.Y., Ou, D.N., Yu, J., Wang, Q., 2006. Organic carbon and nitrogen stable isotopes in the intertidal sediments from the Yangtze Estuary. China Mar. Pollut. Bull. 52, 1625-1633.

Liu, J.F., Xu, Z.S., Wang, L., Sun, Y.B., 2009. Features of climate and water resources evolution in the yellow River Basin. China Water Resour. 13, 23-25 (in Chinese with English abstract).

Liu, D.Y., Li, X., Emeis, K.C., Wang, Y.J., Richard, P., 2015. Distribution and sources of organic matter in surface sediments of Bohai Sea near the Yellow River Estuary, China. Estuar. Coast. Shelf Sci. 165, 128-136.

Ma, M., Feng, Z., Guan, C., Ma, Y., Xu, H., Li, H., 2001. DDT, PAH and PCB in sediments from the intertidal zone of the Bohai Sea and the yellow Sea. Mar. Pollut. Bull. 42, $132-136$.

Mayer, L.M., 1994. Surface area control of organic carbon accumulation in continental shelf sediments. Geochim. Cosmochim. Acta 58, 1271-1284.

Mayer, L.M., Keil, R.G., Macko, S.A., Joye, S.B., Ruttenberg, K.C., Aller, R.C., 1998. Importance of suspended participates in riverine delivery of bioavailable nitrogen to coastal zones. Glob. Biogeochem. Cycles 12, 573-579.

McKinney, R.A., Nelson, W.G., Charpentier, M.A., Wigand, C., 2001. Ribbed mussel nitrogen isotope signatures reflect nitrogen sources in coastal salt marshes. Ecol. Appl. 11, 203-214.

Meyers, P.A., 1994. Preservation of elemental and isotopic source identification of sedimentary organic matter. Chem. Geol. 144, 289-302.

Meyers, P.A., 1997. Organic geochemical proxies of paleoceanographic, paleolimnologic, and paleoclimatic processes. Org. Geochem. 27, 213-250.

Middelburg, J.J., Nieuwenhuize, J., 1998. Carbon and nitrogen stable isotopes in suspended matter and sediments from the Schelde Estuary. Mar. Chem. 60, 217-225.

Middelburg, J.J., Hermann, P.M.J., 2007. Organic matter processing in tidal estuaries. Mar. Chem. 106, 127-147.

Owen, R.B., Lee, R., 2004. Human impacts on organic matter sedimentation in a proxima shelf setting, Hong Kong. Cont. Shelf Res. 24, 583-602.

Pancost, R.D., Boot, C.S., 2004. The palaeoclimatic utility of terrestrial biomarkers in marine sediments. Mar. Chem. 92, 239-261.

Ramaswamy, V., Gaye, B., Shirodkar, P.V., Rao, P.S., Chivas, Allan, R., Wheeler, D., Swe, T., 2008. Distribution and sources of organic carbon, nitrogen and their isotopic signatures in sediments from the Ayeyarwady (Irrawaddy) continental shelf, northern Andaman Sea. Mar. Chem. 111, 137-150.

Ran, L.S., Lu, X.X., Sun, H.G., Han, J.T., Li, R.H., Zhang, J.M., 2013. Spatial and seasona variability of organic carbon transport in the Yellow River, China. J. Hydrol. 498, 76-88.

Regnier, P., Friedlingstein, P., Ciais, P., Mackenzie, F.T., Gruber, N., Janssens, I.A., Laruelle, G.G., Lauerwald, R., Luyssaert, S., Andersson, A.J., Arndt, S., Arnosti, C. Borges, A.V., Dale, A.W., Gallego-Sala, Angela V., Goddéris, Y., Goossens, N., Hartmann, J., Heinze, C., Ilyina, T., Joos, F., Larowe, D.E., Leifeld, J., Meysman, F.J.R., Munhoven, G., Raymond, P.A., Spahni, R., Suntharalingam, P., Thullner, M., 2013. Anthropogenic perturbation of the carbon fluxes from land to ocean. Nat. Geosci. 6, 597-607.

Schlunz, B., Schneider, R.R., Muller, P.J., Showers, W.J., Wefer, G., 1999. Terrestrial organic carbon accumulation on the Amazon deep sea fan during the last glacial sea level low stand. Chem. Geol. 159, 263-281.

Schubert, C.J., Calvert, S.E., 2001. Nitrogen and carbon isotopic composition of marine and terrestrial organic matter in Arctic Ocean sediments: implications for nutrient utilization and organic matter composition. Deep-Sea Res. 48 (pt 1), 789-810.

Tesi, T., Miserocchi, S., Goñi, M.A., Langone, L., Boldrin, A., Turchetto, M., 2007. Organic matter origin and distribution in suspended particulate materials and surficial sediments from the western Adriatic Sea (Italy). Estuar. Coast. Shelf Sci. 73, 431-446.

Thornton, S.F., McManus, J., 1994. Application of organic carbon and nitrogen stable isotope and $\mathrm{C} / \mathrm{N}$ ratios as source indicators of organic matter provenance in estuarine systems: evidence from the Tay Estuary, Scotland. Estuar. Coast. Shelf Sci. 38, 219-233.

Vizzini, S., Savona, B., Caruso, M., Savona, A., Mazzola, A., 2005. Analysis of stable carbon and nitrogen isotopes as a tool for assessing the environmental impact of aquaculture: a case study from the western Mediterranean. Aquacult. Int. 13, $157-165$.

Wada, E., Hattori, A., 1991. Nitrogen in the Sea: Forms, Abundances and Rate Processes. CRC Press, Boca Raton, pp. 208.

Wang, H., Bi, N., Saito, Y., Wang, Y., Sun, X., Zhang, J., Yang, Z., 2010. Recent changes in sediment delivery by the Huanghe (Yellow River) to the sea: causes and environmental implications in its estuary. J. Hydrol. 391, 302-313.

Wang, X.C., Ma, H.Q., Li, R.H., Song, Z.S., Wu, J.P., 2012. Seasonal fluxes and source variation of organic carbon transported by two major Chinese Rivers: the Yellow River and Changjiang (Yangtze) River. Global Biogeochem. Cycles 26. http://dx.doi. org/10.1029/2011GB004130.

Wu, Y., Zhang, J., Li, D.J., Wei, H., Lu, R.X., 2003. Isotope variability of particulate organic matter at the PN in the East China Sea. Biogeochemistry 65, 31-49.

Zhang, L.J., Jiang, B., Zhang, X.S., Liu, J.D., 2008. Study of carbon content tracing sediment diffusion bound after water-sediment regulation in the Yellow River estuary. Adv. Water Sci. 19, 153-159 (in Chinese with English abstract).

Zhang, J., Zhang, L.J., Gong, M.N., 2010. The distribution of hydrocarbons in the surface sediments from the Huanghe Estuary and adjacent area. Acta Oceanol. Sin. 32, 23-30 (in Chinese with English abstract).

Zhou, J.L., Wu, Y., Zhang, J., Kang, Q.S., Liu, Z.T., 2006. Carbon and nitrogen composition and stable isotope as potential indicators of source and fate of organic matter in the salt marsh of the Changjiang Estuary, China. Chemosphere 65, 310-317. 